\author{
Agata RzymetKa-Frackiewicz \\ Teresa Wilk
}

\title{
Odmienność a poczucie bezpieczeństwa, czyli co możemy i co powinniśmy zmienić w naszym myśleniu o Innych w ilustracji filmowo-teatralnej
}

\author{
Sztuka zarysowuje się jako \\ zastugujacy na uwage "instrument" \\ kształcenia człowieka, nie tylko \\ w zakresie jego kultury estetycznej, \\ lecz $i$ we wszystkich innych \\ zakresach przeżyć i działań. \\ Irena Wojnar
}

Streszczenie: Jednym z wielu obrazów współczesności jest wzajemne funkcjonowanie osób reprezentujących odmienne kultury, narodowość, rasę czy religię. To sprawia, że w poszczególnych społecznościach pojawia się szereg nieporozumień czy konfliktów, powodowanych brakiem wiedzy o wzajemnej kulturze. Rysująca się coraz powszechniej odmienność we współczesnych społeczeństwach generując wielorakie obawy i lęk uniemożliwia zachowanie poczucia bezpieczeństwa. Tymczasem odmienność/różnorodność kulturowa, etniczna, narodowa winna być postrzegana jako wspólne dobro służące budującym się wspólnotom. Tym samym ujawnia się brak świadomości, że odmienność kulturowa to wartość, swoiste bogactwo warunkujące szerokie możliwości holistycznego rozwoju, a nie zagrożenie tożsamości czy wolności. By stan taki osiągną potrzeba świadomości i wiedzy.

Niniejszy tekst jest zatem próbą zainteresowania społeczeństwa przedmiotowym zagadnieniem, które można oswoić i rozwinąć dzięki edukacji międzykulturowej, która może przybrać różne formy edukacji, także poprzez poszczególne dziedziny sztuki, takie jak teatr czy film. Wspomniane dziedziny sztuki stanowią nie tylko pole edukacji, poznania różnorodności, ale są narzędziem kształtowania postaw, zainteresowań, wyrażania emocji czy modelowania sposobu myślenia o odmienności.

Propozycje konkretnych (wybranych) spektakli czy filmów, oparto zasadniczo na pełnym przekonaniu, że sztuka stanowi nie tylko wartość autoteliczną, 
A. RZYMEeKa-FrąCKIEWICZ, T. WilK $\$$ OdMIENNOŚĆ A POCZUCIE BEZPIECZEŃNTTWA 327

artystyczną, ale jest narzędziem formującym kierunek myślenia w określonym zakresie.

Słowa kluczowe: odmienność, bezpieczeństwo, myślenie, sztuka, edukacja międzykulturowa

\section{Na początek}

Gdyby próbować charakteryzować obawy, jakich doświadczają współczesne społeczeństwa, musiałybyśmy wymienić cały szereg zjawisk, sytuacji, urządzeń z obszarów m.in.: chemicznego, fizycznego, technicznego, biologicznego, medycznego czy społecznego. Każdy ze wspomnianych obszarów generuje określone lęki, postawy i zachowania, modelowane przez nie w perspektywie powszechnych aktywności. Sytuacje te nie stanowią stricte nowego zagadnienia w dziejach ludzkości, ale z pewnością w społeczeństwie ryzyka (Beck, 2002) czy płynnej nowoczesności (Bauman, 2006, 2011) nabierają nowego wymiaru, poprzez różnorodność uwarunkowań, przejawy oraz ich konsekwencje.

Pośród wyróżnionych obszarów obaw i lęków pragniemy zwrócić uwagę na obszary społeczne, w których niezmiennie realizujemy swoją codzienność, która warunkuje realizację potrzeb i aspiracji, a jednocześnie stwarza sytuacje lękowe, uniemożliwiające lub utrudniające codzienne aktywności.

„Lęk jest złożonym zjawiskiem, które zarówno w wymiarze indywidualnego doświadczenia oraz jako przedmiot badań naukowych odnosi się do sfery niepewności, co niewątpliwie sprzyja sprzecznym interpretacjom i ocenom dotyczącym podstawowych przyczyn, cech definicyjnych, a także roli, jaką lęk odgrywa w naszym życiu" (Wilkinson, 2008, s. 856). Lęk to konsekwencja wzajemnego oddziaływania prezentowanych (przeżywanych) emocji, reakcji fizycznych i behawioralnych (Wilkinson, 2008, s. 856).

W tekście posługujemy się zamiennie dwoma terminami - obawy i lęku. Czynimy to w pełni świadomie, ponieważ, w naszym rozumieniu, terminy te odnoszą się do tych samych aspektów, zmieniać się mogą zasadniczo w zakresie nasilenia emocjonalnego i kontekstów użycia danego terminu, obawiamy się bowiem czegoś lub kogoś, a czujemy lęk przed czymś lub przed kimś. Ponadto ilustrują one podobne stany emocjonalne wynikające z nieznajomości tudzież niewiedzy o kimś lub o czymś.

Obserwując codzienność społeczną, można odnieść wrażenie, że najpowszechniejsze obawy czy lęki reprezentowane przez społeczeństwo związane są współcześnie z obecnością w naszej, oswojonej przez lata przestrzeni, re- 
prezentantów odmiennych kultur, narodowości, grup etnicznych osób wyznających religie identyfikowane z toczącymi się - w różnych rejonach świata - konfliktami na tle religijnym lub kulturowym.

\section{Kultura i sztuka jako narzędzie dialogu w przestrzeni społecznej}

Historia ostatnich dekad, w których fascynowała nas globalizacja, ukazuje, że niemal już u jej „nowej odsłony” (w początkach transformacji) dostrzegano jej dobrodziejstwa oraz jej negatywne konsekwencje, które dynamicznie rozprzestrzeniały się w społecznych przestrzeniach. Nieustanne dążenie do rozwoju cywilizacji, dobrobytu i nieograniczonej konsumpcji skutecznie przesłoniły możliwości reinterpretacji owej wszechświatowej formuły, którą przyjmowaliśmy i wprowadziliśmy, ale gdy ukazała ona ludzkości swoje mniej przychylne oblicze, nie potrafimy oswoić tych negatywnych skutków. Rzeczywistość coraz jaskrawiej ujawnia, że podejmowane rozwiązywania problemów społecznych w znacznym stopniu nie sprawdzają się. To generuje trudności w realizacji codziennych zadań i aspiracji, nie sprzyja poczuciu stabilizacji ani bezpieczeństwa, nie ułatwia budowania identyfikacji oraz kreowania niezbędnych społecznych więzi. Tym samym rzeczywistość budzi powszechne obawy i lęki doświadczane przez wszystkie grupy społeczne.

Obawy codziennego życia dotyczą wszystkich mieszkańców danego środowiska, co znaczące, w coraz szerszym zakresie zróżnicowanego kulturowo. W tym kontekście pojawia się kilka pytań: czy wszyscy w pełni identyfikują się z przestrzenią w której żyją, czy czują się współtwórcami otaczającej rzeczywistości, czy tylko konsumentami oferowanych propozycji? W jakim zakresie rzeczywistość pozwala na realizację indywidualnych zamierzeń? Jak kształtują się relacje w społeczeństwie, w którym żyją? Czy wszyscy czują się równoprawnymi członkami środowiska, korzystającymi w pełni z wszelkich dostępnych dóbr społecznych? Poszukując odpowiedzi na postawione pytania, zauważamy, że nawet pobieżna obserwacja rzeczywistości, nasyconej szeregiem sytuacji problemowych, ujawnia odmienne możliwości realizacji indywidualnych powinności i funkcji. To również znacząco zróżnicowany dostęp do wszelkich dóbr społecznych. Owo zróżnicowanie dotyczy zarówno mieszkańców z dawien dawna zamieszkujących owe tereny, jak również emigrantów, przybyszów z różnych krajów i kontynentów.

Rysujące się w przestrzeni rodzimej czy europejskiej przejawy destabilizacji społecznego funkcjonowania i nierówności w dostępie do dóbr społecznych, 
A. RZYMEeKa-FrącKieWICZ, T. WilK $\$$ OdMIENNOŚĆ A POCZUCIE BEZPIECZEŃNTTWA 329

będące udziałem - w znacznym stopniu - środowisk wielokulturowych, są potwierdzeniem deficytu wiedzy, świadomości i zaufania wobec człowieka, niezależnie jaką kulturę/grupę etniczną reprezentuje. Sytuacja taka znacząco ogranicza możliwość sprawnego, zorganizowanego współdziałania i zachowania bezpieczeństwa. A tymczasem to zorganizowanie współdziałania, a także zachowanie porządku społecznego oraz zaufania warunkują poczucie bezpieczeństwa i stabilizacji. Poznanie odmienności i wypracowanie/okazywanie zaufania, kategorii opartej na wzajemności, wiarygodności, odpowiedzialności i szacunku, to podstawy budowania wspólnej wielokulturowej przestrzeni (Hardin, 2008, ss. 525-534).

W sytuacji tak powszechnie występującej odmienności/różnorodności kulturowej, narodowej, religijnej, tworzeniu bezpiecznej przestrzeni wspólnego życia niezbędny jest dialog prowadzący do akceptacji, tolerancji i szacunku. Już w przeszłości w zróżnicowanych środowiskach wprowadzano dialog do społecznej sieci funkcjonowania, dostrzegając w nim potencjał porozumienia. I w dobie obecnej dialog jest postrzegany jako kluczowe narzędzie pozwalające na bezpieczną wspólnotowość. Jeżeli współczesne społeczności uznają wartość dialogu, to pojawia się pytanie, dlaczego w przestrzeniach życia tak wiele konfliktów i nieporozumień. Pośród wielu odpowiedzi, jedną $\mathrm{z}$ podstawowych wydaje się ta wskazująca na niewielkie powszechne zainteresowanie reprezentantów odmiennych kultur wzajemnym dialogiem. Trudno osiągnąć pozytywny efekt w danym zakresie, jeżeli tylko część społeczeństwa posiada świadomość potrzeby nieustannego dialogu.

A dialog prowadzący do porozumienia, bezpiecznego współistnienia można prowadzić w różnych formach, poza bezpośrednim spotkaniem i wymianą myśli, komunikacją pośrednią poprzez media, dialog można prowadzić także poprzez artystyczne wytwory reprezentantów różnych kultur, czyli poprzez sztukę. W perspektywie historyczno-społecznej pojawia się szereg przykładów ukazujących możliwości wzajemnej komunikacji, poprzez powszechne włączenie do codzienności kultury i sztuki.

Kultura jest jednym z najczęściej używanych pojęć w naukach humanistycznych i społecznych, oznaczając pielęgnowanie tego, co już zostało stworzone, i stanowi określoną wartość, jak i realizację potrzeb i działań, które mają dopiero przynieść oczekiwane rezultaty. Człowiek niezmiennie, niezależnie od czasu społeczno-historycznego, realizuje swoje życie w określonej przestrzeni oraz kulturze. Nie sposób nie zauważyć, że w podstawowych dyscyplinach społecznych definiowanie kultury jest niemal tożsame, ujmuje bowiem te aspekty, które konstytuują życie człowieka, umożliwiając mu realizację potrzeb i aspiracji. 
W działaniach modelujących społeczne funkcjonowanie nie tylko kultura odgrywa kluczową rolę, ale także każde dzieło sztuki, prezentujące poza artystycznym kunsztem, wiedzę, umiejętności, wartości i postawy twórców, i najczęściej - zapewne subiektywne - piękno.

„Sztukę tworzy człowiek z dźwięków, kształtów, barw, ruchu. Tworzy ją po to, aby była łącznikiem między nim, a innymi ludźmi. Tworzy ją tak, aby w rozmaity sposób mogła przekazywać obraz świata odbity w ludzkiej psychice, a także ukazywać ludzkie myśli, przeżycia, zamiary. [...] Ale to, czy uda się widzowi dostrzec wartości sztuki, jak głęboko przeniknie ona w jego osobowość, jakie skutki zostawi - zależne jest w dużej mierze od tego, czy zechce i potrafi on zostać współpartnerem sztuki, czy będzie umiał sam szukać w niej wartości, wybierać je, akceptować lub odrzucać" (Hohensee-Ciszewska, 1976, s. 6). Czy uda się osiągnąć wspomniane zadania, zależy od edukacji, realizowanej zarówno w środowisku rodzinnym/domowym, jak i w środowisku szkolnym. W realiach współczesności to szkole przypisuje się szereg zadań zorientowanych na ukształtowanie jednostki, która zdoła samodzielnie i odpowiedzialnie realizować swoje powinności w zróżnicowanym społeczeństwie. Edukacja niezmiennie pozostaje formą spotkania i dialogu pomiędzy nauczycielem a uczniem. To w tym układzie realizują się podstawy i świadomość potrzeby prowadzenia skutecznego dialogu. Dlaczego nie wspomaganego sztuką?

Sztukę jako zasadniczy aspekt spotkania między ludźmi wprowadza do społecznej przestrzeni Joseph Beuys (1990). Jego koncepcja Rzeźby społecznej jest klarownym przykładem kompozycji sztuki, przede wszystkim rzeźby oraz koncepcji pedagogicznych. W zamyśle tego niemieckiego teoretyka sztuki, artysty/rzeźbiarza, wytwory i akcje/projekty artystyczne miały stanowić asumpt do społecznej dyskusji o otaczającej rzeczywistości i uwarunkowaniach codziennej ludzkiej egzystencji w dobie coraz jaskrawiej ujawniającej się destabilizacji polityczno-ekonomiczno-społecznej. Wspomniany artysta postrzegał siebie nie tyle jako twórcę sztuki, ale jako pedagoga/reformatora otaczającej - już kilka dekad temu - zróżnicowanej rzeczywistości. W zamyśle tego kreatora i wizjonera rysowała się wizja nowego społeczeństwa, które może powstać w wyniku zaangażowania pedagogiki oraz odpowiedniego systemu edukacji.

Pośród wielu dyscyplin sztuki naszą uwagę kierujemy ku dwóm dziedzinom: teatrowi i filmowi. Bo każda z nich to idealna kompozycja pozostałych dziedzin sztuki, to niemal nieograniczone możliwości ilustracji ludzkiego życia, to artystyczny wyraz emocji i doświadczeń artysty czerpiącego pomysł do swego projektu z codzienności losów ludzkich. W tym kontekście 
A. RZYMEeKa-FrąCKIEWICZ, T. WilK $\$$ OdMIENNOŚĆ A POCZUCIE BEZPIECZEŃNTTWA 331

każde dzieło sztuki staje się - jak chciał Beuys - komunikatem społecznym, zaproszeniem do dyskusji, wymiany refleksji, materiałem do kreowania pożądanych relacji społecznych.

Materiały źródłowe ujawniają, że: „ludzie powołali teatr z obrzędu tanecznego, by opowiadał im historie, w których mogliby - na zasadzie podobieństwa bądź reprezentatywności - ujrzeć samych siebie. Za najlepszy sposób przedstawiania takich opowieści uznali przeobrażenie się opowiadającego - a wcześniej tańczącego - w inną postać, w inne »ja «. Tak było wiele tysięcy lat temu, tak jest i dzisiaj" (Chymkowski, Dudzik i Wójtowski, 2003, s. 127). Teatr to sugestywna sztuka, której przesłanie można odczytać nawet poza werbalnym komunikatem. Teatr bowiem to nie tylko słowo, ale emocje, ruch, kostiumy, scenografia i muzyka, kategorie, które można odczytać bez użycia słów.

Nie bez racji William Inge twierdził, że: „[...] dobra sztuka wyjaśnia życie, [...] Autor powinien dać możność dokonania własnego wyboru. Jak się zabrać do tego? Bardzo prosto: wierzyć, że widz przychodzi do teatru nie po to, by mu coś powiedziano, ale by samemu coś odkryć - coś, co jest ważne dla niego" (Inge, 1958, za Hausbrandt, 1983, s. 82). W tym kontekście sztuka teatralna jawi się jako swoiste laboratorium, gdzie bezpośrednie i pośrednie doświadczenie sztuki, jej treści i formy, pozwala oswoić własne trudności i niepokoje.

Alain Schneider z kolei pisał: „Teatr jest dla mnie sztuką, która uczy żyć, tłumaczy życie, objaśnia i komentuje. Pokazując człowieka przenika warstwy najtajniejszego życia. [...] Sztuka to obraz życia zagęszczony, wzbogacony o nowe spostrzeżenia, głębszy. Odkrywa w nas samych jakieś wartości, których być może nie przeczuwamy na co dzień [...]. Celem głównym teatru jest przekazanie nam jakichś nowych doświadczeń, skierowanie naszej uwagi na nową problematykę życia ludzkiego" (Schneider, 1961, za Hausbrandt, 1983, s. 87). I z tą refleksją trudno się nie zgodzić. Teatr jawi się jako zwierciadło ludzkiej egzystencji, a równocześnie jako narzędzie dialogu.

Od początków dziejów ludzkości towarzyszy człowiekowi w jego codziennej wędrówce teatr, a od XX wieku pojawia się film, który uzupełnia funkcje sztuki teatralnej, a dzięki właściwym środkom wyrazu znakomicie ją wspomaga i pozwala w jeszcze większym, powszechniejszym zakresie dotrzeć do masowego widza, prezentując tematykę, której źródłem są doświadczenia ludzkich losów. Trafnie zauważała Irena Wojnar, że w XX wieku pojawiła się sztuka: „dla której prezentacja obrazu świata stanowi zadanie podstawowe, sztuka której udało się pogodzić odwieczną sprzeczność między przestrzenią a czasem" (1984, s. 114). Tą dziedziną sztuki był film, za sprawą którego wiek 
XX nazywano „wiekiem filmu”. Film „to pojęcie ogólne (jak piśmiennictwo czy muzyka) oznaczające wszystko, co wynika ze zjawiska ekranowego i jego różnych form oraz zastosowań. A więc - utwór (komunikat) filmowy to nie tylko dzieło sztuki. To tekst kulturowy" (Lewicki, 1984, s. 13). Jest zatem film nie tylko artefaktem, ale obrazowo-słownym komunikatem językowym. Jest ilustracją codziennych zmagań człowieka, ilustratorem emocji i przeżyć, trudnych i radosnych doświadczeń indywidualno-społecznych.

„Film decyduje w dużym stopniu o kierunku ewolucji w postawach i w postępowaniu człowieka. Pod wpływem oglądania i przeżywania sztuki filmowej, na skutek działania swoistego języka filmowego, u coraz liczniejszych pokoleń widzów filmowych zmienia się charakter przeżyć estetycznych i form kontaktu ze sztuką" (Wojnar, 1970, s. 31). Jeszcze szerzej znaczenie/ funkcje filmu postrzegał Epstein. „Kultura kinematograficzna (...) rozszerza świadomość człowieka, wysubtelnia myśli, popularyzuje układy przestrzeni odkryte już dawniej przez mikroskop (...). Prowadzi nas dalej niż luneta i mikroskop, gdyż ukazuje nowe układy i rytmy czasu. »Nieprędko - pisze Epstein w „Duchu filmu” - nauczymy się korzystać z tej zdobyczy, nie od razu myśl nasza nauczy się poruszać równie szybko w czasie, jak w przestrzeni, ale tę zdobycz, która fundamentalnie przekształci naszą kulturę, będziemy zawdzięczali kinematografii «" (Gawrak, 1962, s. 214).

Zatem zarówno teatr, jak i film, zachowując swoje artystyczne przymioty, spełniają szereg funkcji edukacyjnych i społecznych, pozwalających ze sceny czy z ekranu dostrzec/odczytać widzom to, czego nie dostrzegają w codziennym życiu. To możliwość odniesienia sytuacji fabularnej/scenicznej/ filmowej do własnych doświadczeń. To przestrzeń szerokiego poznania/edukacji i kształtowania dialogu, tym samym uwarunkowań możliwych refleksji i zmian postaw wobec siebie i wobec drugiego człowieka.

\section{Teatr i film jako przestrzeń poznania i edukacji w perspektywie myślenia o innych ${ }^{1}$}

Obserwacja codzienności, zachowań i aktywności indywidualnych oraz społecznych, kształtuje w obserwatorze rodzaj myślenia o innych, o ich postawach, środowiskach działania, relacjach społecznych. To nie jedyna przesłan-

1 Tę część artykułu opracowałyśmy w kontekście przywołanych treści oraz analiz wybranych spektakli teatralnych i filmów ilustrujących przedmiotowe zakresy tematyczne. 
A. RZYMEeKa-FrąCKIEWICZ, T. WILK $\&$ OdMIENNOŚĆ A POCZUCIE BEZPIECZEŃSTWW 333

ka regulująca myślenie o innych, ale z pewnością bardzo czytelna i wnosząca szereg informacji. Równie dobrym, a może jeszcze lepszym polem poznania i generowania sposobu myślenia o innych jest sztuka: teatralna i filmowa. Ich forma, prezentowane treści, wyzwalające emocje oraz estetyka obrazu umożliwia skupienie się na danym obszarze tematycznym i pełniejszym poznaniu uwarunkowań danego zachowania. Poczynione obserwacje, przeżyte doświadczenia moga „przenieść się” w realia codziennych kontaktów i relacji społecznych. Mogą je odpowiedzialnie modelować.

Po paryskiej wielce udanej premierze sztuki Geralda Sibleyarsa Napis w 2004 roku, w krótkim czasie staje się ona żelaznym repertuarem wielu teatrów europejskich. Także w naszym kraju kilka scen dramatycznych podejmuje się realizacji tej sztuki, m.in. Teatr Współczesny w Warszawie, w którym w maju 2005 roku, odbywa się prapremiera tej czarnej komedii, w reżyserii Macieja Englerta.

Pewnego razu w porządnej paryskiej kamienicy dochodzi do nieprzyjemnego incydentu, pojawia się obelżywy napis dotyczący państwa Lebrun nowych lokatorów. Poruszony napisem lokator postanawia dociec, kto jest autorem tego niewybrednego ataku. Akcja rozgrywa się w mieszczańskim, współczesnym środowisku paryskim, pośród trzech politycznie poprawnych małżeństw. Podjęte dochodzenie w grupie sąsiadów, w pozornie tylko błahej sprawie, mocno poruszy zasady spokoju i dobrego samopoczucia sąsiadów. Inteligentne towarzystwo, prezentujące wydawać by się mogło pożądany poziom kultury i relacji międzyludzkich, stosunkowo szybko ujawnia swoje prawdziwe oblicze. Osoby uchodzące za spokojne, zrównoważone, zmieniają się w stado hien, ilustrując konflikt między starymi a nowymi mieszkańcami. A wszystko przez napis - Lebrun=con (głupek) - ujawniony w windzie. Sąsiedzi spotykają się w kolejnych mieszkaniach, prowadząc dyskusje nie tylko w sprawie napisu, ale także innych mniej lub bardziej poprawnych politycznie zachowań, wobec odmienności seksualnej, religijnej, kulturowej czy odmiennej narodowości. Czy rysujące się różnice pozwolą na budowanie wspólnoty w dobie wielokulturowości? Pojawiają się pytania, czy inne napisy w windzie, np. śmierć faszystom, są bardziej obelżywe i dla kogo. To kolejny obszar wywołanej dyskusji wśród sąsiadów. Dodatkowym nietaktem ze strony Lebruna jest jego wizyta u sąsiadów w porze wieczornego posiłku, dla Francuzów to wielkie faux pas. Spektakl ten to przykład mocnego osadzenia w realiach kulturowych. Pokazuje, jak trudno odnaleźć się w nowej kulturze, nasyconej niuansami, które niekiedy przybierają znaczącą perspektywę wzajemnych relacji. 
Spektakl ujawnia szereg sytuacji, zachowań odbiegających od obowiązujących, przypisanych pewnym grupom społecznym, norm. To obraz naszego stosunku do obcych, imigrantów, przybyszów z dalszej lub bliższej przestrzeni. Z pewnością różniących się od większości. Pozornie błahe zdarzenie prowadzi do kryzysu, ukazującego powierzchowność relacji, brak tolerancji i zaufania maskowanymi konwenansami. Autor bezlitośnie krytykuje współczesne społeczeństwo, ostrzegając przed niebezpieczeństwem utraty niezależności, zaufania, poczucia bezpieczeństwa, postępującej obawy wobec Innego/Obcego, jego kultury i przekonań. Rama przyzwoitości społecznej ulega deformacji. Jak niewiele trzeba, by wyzwolić z człowieka, jego prawdziwe, ale niepożądane oblicze. Spektakl stawia szereg pytań: Kim są sąsiedzi stanowiący pewną zbiorowość? Co warunkuje ich sposób myślenia o nowych sąsiadach? Czy znajdzie się autor obelżywego napisu? Jak zachowają się mieszkańcy w nowej/doświadczanej sytuacji? Kim okaże się autor napisu? Czy napis zawiera prawdę, czy może jego autor próbuje danej społeczności zwrócić uwagę na coś istotnego, co kryje się za tym napisem? Czy nasze, powszechne zachowania, sugerują, że już przyzwyczailiśmy się do wulgarnych napisów w przestrzeni społecznej? Wreszcie, czy Francuzi obywatele świata - kroczący dumnie w awangardzie postępu i multi-kulti, zdają egzamin, w tak specyficznej/powszechnej sytuacji? Czy nie powinniśmy skierować tego pytania do innych narodów? To pytania do widzów, to my na podstawie treści ukazanych w spektaklu oraz własnych obserwacji i refleksji powinniśmy odpowiedzieć na postawione pytania, kolejni reżyserzy służą nam tylko - poprzez przedstawioną sztukę - podpowiedzią, motywują do namysłu, a odpowiedź, to już zadanie widzów (społeczeństwa).

Innym przykładem sztuki teatralnej ukazującym perspektywę oswajania odmienności kulturowej jest spektakl Transfer w reżyserii Jan Klaty, którego premiera miała miejsce w Teatrze Współczesnym we Wrocławiu w 2006 roku. Spektakl to opowieść o losach polskich i niemieckich wypędzonych. Głównymi bohaterami tego przedstawienia jest grupa 10 osób dzielących się swoimi przeżyciami z okresu przesiedlenia: Polacy z Kresów na ziemie odzyskane oraz Niemcy z terenów Polski zachodniej do Niemiec. Tych 10 osób reprezentuje miliony przesiedlonych, doświadczających konsekwencji wojny oraz rozstrzygnięć jałtańskich, stanowiących nowy porządek w Europie, także w sprawie obecnych granic. Zasadniczym wątkiem spektaklu, wpisującym się w tematykę naszych rozważań, są nie tylko trudy adaptacji w nowym, nieznanym/obcym środowisku, ale szczególnie ważne poznawczo są wątki opisujące okres przejściowy w życiu przesiedlonych, czyli okres/czas, kiedy 
A. RZYMEeKa-FrąCKIEWICZ, T. WILK $\&$ OdMIENNOŚĆ A POCZUCIE BEZPIECZEŃSTWW 335

to Niemcy jeszcze nie opuścili swoich domów na zachodzie Polski, a Polacy już pojawili się w tej (nowej dla nich) przestrzeni. Znamienne w tych opowieściach jest to, że reprezentanci - jeszcze w grudniu 1944 roku - wrogich stron: Polski i Niemiec, w szczególnym czasie świątecznym, potrafią siąść przy wspólnym stole, łamać się opłatkiem w czasie wigilii oraz śpiewać kolędy w dwóch językach. Ten czytelny przykład tęsknoty za wolnością jest jednocześnie wyrazem wybaczenia i tolerancji. Czy wybaczenie było prawdziwe, tego nie wiemy, ale na pewno, dzięki wspólnym dążeniom i zaangażowaniu, oraz wyjątkowemu, świątecznemu czasowi udało się zbudować bezpieczną przestrzeń. Ten specyficzny spektakl, oparty na indywidualnym doświadczeniu/przeżyciu bohaterów ukazuje, że już w przeszłości obserwowano dążenia ludzi, nawet o odmiennej narodowości czy kulturze, do kreowania zróżnicowanej wspólnoty. Spektakl jest zatem doskonałą lekcją historii dla młodego pokolenia, a wypowiedzi osób doświadczających przesiedlenia ostrzeżeniem przed przyszłością, która może przynieść wiele złego, jeżeli już dzisiaj o nią odpowiednio nie zadbamy, czyli nie podejmiemy świadomych działań oświatowych.

Edukacja w obszarze odmienności/wielokulturowości to współczesne zadanie dla wszystkich społeczności, które są zainteresowane i świadome obecnych realiów, które nie mogą zatrzymać ruchów migracyjnych, przemieszczania się zróżnicowanej kulturowo ludności. Aktywność społeczna wyrażająca się w nieograniczonym niemal przemieszczaniu się pomiędzy państwami czy kontynentami powoduje konieczność podejmowania określonych działań służących przygotowaniu społeczeństw poszczególnych państw do wielokulturowego współistnienia.

Obok sztuki teatralnej również sztuka filmowa podejmuje interesujący nas zakres tematyczny. Może w jeszcze większym zakresie, z uwagi na środki przekazu, formułę filmu, zagadnienia podejmowane w fabule lub dokumencie filmu, ta dziedzina sztuki może dotrzeć do większej zbiorowości odbiorców. Może tym samym wzbudzić do refleksji i pożądanej przemiany wspólnoty społeczne doświadczające wielu trudności, obaw, zwłaszcza w tak zróżnicowanych kulturowo przestrzeniach.

Znakomitym przykładem potrzeby oswajania odmienności, budowania pojednania dla wspólnej przestrzeni życia jest film Joanny Kos-Krauze i Krzysztofa Krauze: Ptaki śpiewają w Kigali (2017), będący w podstawowym przesłaniu - ostrzeżeniem przed kolejnym Holokaustem. Autorzy zasadniczo nie prezentują bratobójczej walki pomiędzy dwoma plemionami, wystarczy, że jest ona czytelnym tłem, przestrzenią, w której autorzy ukazują porusza- 
jącą relację pomiędzy Anną, polską ornitolożką badającą wraz z rwandyjskim profesorem ptaki w Afryce, oraz jego córką Claudine, cudem uratowaną przez Annę z pogromu w czasie ludobójstwa dokonanego w Rwandzie. Obu bohaterkom udaje się uciec z kraju tak boleśnie doświadczonego bezmyślnością, deficytem odpowiedzialności i szacunku wobec drugiego człowieka. Roszczenia czy dążenia ludzi - reprezentujących odmienne plemiona - ale jednocześnie tę samą kulturę, ujawniają ogromne deficyty edukacyjne i cywilizacyjne tego społeczeństwa, brak potrzeby prowadzenia rozmów zorientowanych ku porozumieniu, brak kultury dialogu. Dążenie do zwycięstwa, osiągnięcia określonych dóbr przez jedną społeczność przesłania jakąkolwiek skłonność do porozumienia, wypracowania kompromisu.

Powrót, a dla Claudine przyjazd, do Polski nadal epatuje pamięcią śmierci i bolesnych doświadczeń pomimo pokoju i bezpieczeństwa, to celowy zamysł autorów, że pewnych wspomnień nie da się wymazać z pamięci, a może nie powinno się tego czynić, bo one stale ostrzegają przed niezmiennie czyhającym niebezpieczeństwem.

Konflikty ekonomiczne, społeczne, polityczne czy kulturowe w dobie obecnej dzieją się wszędzie, nawet w krajach, które wydają się być bezpieczne. Inny jest tylko zakres i skala, ale przecież i to się może zmienić. Dlatego tak istotna jest wszelka edukacja, także ta międzykulturowa, która niesie nadzieję porozumienia.

Dobrym przykładem inicjującym edukację międzykulturową jest przykład swoistej diagnozy społecznej współczesnych narodów, autorem której jest Yann Arthus-Bertrand. Twórca ten zrealizował film 7 miliardów innych, który prezentuje wypowiedzi - ludzi pochodzących z różnych kontynentów i krajów - w określonych obszarach tematycznych: Czego nauczyłeś się od swoich rodziców? Co chciałbyś przekazać swoim dzieciom? Co jest najważniejsze w życiu? Czym jest dla ciebie miłość? Czego się boisz? Prezentowany film oparty, podobnie jak spektakl Jana Klaty, na bezpośrednich wypowiedziach bohaterów, to doskonała perspektywa poznania realiów oraz oczekiwań ludzi prezentujących tak odmienne kultury, ale w oczekiwaniach życiowych tak podobnych. Wypowiedzi niezmiennie ujawniają, że ludzie, niezależnie z jakiego kontynentu czy kraju, pragną pokoju, szacunku i miłości. To wartości, które niezmiennie towarzyszą człowiekowi w jego wielowiekowej wędrówce.

Opisywane od lat zjawisko multi-kulti obserwujemy najczęściej w rozproszeniu społecznym, co nie zmienia jego czytelności i obecności w danym środowisku. Można też zobaczyć to zjawisko w bardziej zintegrowanej formie, 
A. RZYMEeKa-FrąCKIEWICZ, T. WilK $\$$ OdMIENNOŚĆ A POCZUCIE BEZPIECZEŃNTTWA 337

zarówno w naturze, jak i w wersji filmowej. Przykładem jest film Szkoła Babel w reżyserii Julie Bertuccelli, powstały we Francji w 2015 roku. To dokument ukazujący - w niemal wzorcowym wydaniu - zjawisko multu-kulti. Głównym obrazem jest klasa szkolna, której 24 uczniów reprezentuje 24 kraje, z których pochodzą. Przyjechali do Francji w poszukiwaniu bezpiecznego życia, w perspektywie społecznej, edukacyjnej i socjalnej. Uwarunkowania tej decyzji były mocno zróżnicowane, aspekty ekonomiczne, polityczne, religijne i kulturowe.

Klasa ta to prawdziwa wieża/(szkoła) Babel, różne narodowości, grupy etniczne, religie oraz języki, a mimo tych różnic grupa tych uczniów ujawnia zdecydowanie więcej elementów spójnych, wyrażających się w poszukiwaniu/pożądaniu szeroko rozumianego bezpieczeństwa, możliwości realizacji podstawowych potrzeb oraz kształtujących się aspiracji.

Film jest dokumentem prezentującym szczere rozmowy prowadzone z młodzieżą przez autorkę. W filmie szczególną uwagę zwraca sytuacja czarnoskórej Ramy, dziewczyny, która ma pozostać na drugi rok w klasie przygotowawczej. Decyzja rady pedagogicznej jest dla dziewczyny niesprawiedliwa. Uważa, że decyzja ta nie jest podyktowana względami merytorycznymi, ale faktem, że jest czarnoskóra. Na „drugim biegunie” można wskazać Polkę, która też przynależy do tej klasy, ale wydaje się nie mieć żadnych problemów, realizuje wytyczne, uczy się języka i w pełni odnajduje w grupie rówieśników. Przykład czarnoskórej Ramy ujawnia jednak, że funkcjonujące w przestrzeni społecznej dorosłych stereotypy odczytywane są także przez młode pokolenie, któremu - nawet jeżeli tak naprawdę wszelkie aktywności kierowane do nich nie mają nic wspólnego z uprzedzeniem czy rasizmem - trudno w to uwierzyć. Film ujawnia, że młodzi ludzie pomimo istotnych wielu różnic potrafią się między sobą porozumiewać. Wspólne doświadczenia przebywania w jednej klasie szkolnej, realizacji czasu wolnego powodują, że pomiędzy poszczególnymi uczniami nawiązują się bliższe relacje. Przez co następuje samorzutna edukacja międzykulturowa. Sytuacja zaczyna się komplikować, kiedy w te relacje ingerują dorośli. Czy to powszechne zachowanie, trudno jednoznacznie określić, na pewno jednak dotyczy wielu przedstawicieli ras odmiennych od dominującej w Europie rasy białej.

Podobny przykład klasy szkolnej, zróżnicowanej etnicznie, odnajdujemy w rodzimych realiach. I chociaż nie jest to materiał filmowy, to chcemy go przedstawić, bo znacząco nawiązuje do zaprezentowanego filmu, i tak naprawdę historia ta mogłaby być dobrym scenariuszem nie tylko dokumentu. Już od lat 90. dyrektorka Społecznego Liceum Ogólnokształcącego oraz Społeczne- 
go Gimnazjum w Warszawie (w czasach kiedy ten typ szkoły obowiązywał) Krystyna Starczewska przyjmowała do szkoły uczniów - uchodźców, uciekinierów z krajów dotkniętych wojnami, konfliktami społecznymi, kulturowymi i religijnymi. Uczniowie z klas multi-kulti pochodzili z Afganistanu, Armenii, Białorusi, Czeczeni i Ukrainy, ale także z Chin, Wietnamu czy Somalii.

Wspomnienia z czasów tworzenia klas zróżnicowanych kulturowo ujawniają, między innymi, trudności i głosy sprzeciwu rodziców wobec przyjmowania muzułmańskich uchodźców. W toku toczących się dyskusji przeciwstawiających się uchodźcom jeden z rodziców skierował kilka pytań do rodziców: „»czy państwo żałowaliby pieniędzy na pomoce szkolne«? Rodzice odpowiedzieli: »no, skąd«. »A czy państwo chcieliby, żeby nasze dzieci podróżowały i poznawały inne kultury«? »No, oczywiście«. »To niech państwo pomyślą, że obecność w szkole uchodźców z różnych stron świata będzie czymś w rodzaju pomocy naukowej dla naszych dzieci, dzięki ich obecności poznawać będą inne kultury, uczyć się tolerancji i akceptacji różnorodności «" (Winnicka, 2015, s. 27). Ten przywołany głos rodzica spowodował, że rodzice przestali kwestionować możliwość przyjmowania uchodźców.

Uczniowie cudzoziemcy rozpoczynają naukę w klasach multi-kulti, dzieci przez rok uczą się języka i kultury polskiej, a potem trafiają do klasy pierwszej realizującej program szkolny. W szkole istnieje także Klub Wielokulturowy. Raz w miesiącu organizowane są spotkania, na których prezentujemy tradycje/kulturę krajów, z których pochodzą uczniowie. To znacząco uczy akceptacji odmienności.

W szkole, jak w każdej społeczności, zdarzają się konflikty wynikające z różnic religijnych i kulturowych, ale te próbuje się oswoić, wskazując na podstawowe wartości, bezpieczeństwo człowieka i szacunku do niego i dla kultury/religii własnej i obcej. To podstawa budowania społeczeństwa wielokulturowego. Uczymy, jak podkreśla dyrektorka, że trzeba akceptować i szanować odmienność, jeżeli chcemy budować wspólną przestrzeń życia. Obserwacja zachowań uczniów, a zwłaszcza absolwentów wskazuje, że uczniowie z czasem to rozumieją i prezentują w swoim życiu.

W tej międzykulturowej edukacji pomaga często sztuka. Tak było i w opisywanej szkole, kiedy podjęto próbę budowania szacunku wobec Żydów, w sytuacji, gdy jeden z uczniów uporczywie stosował obraźliwe przezwiska i dowcipy, będąc przy tym bardzo agresywnym. Dyrektorka wspomina, że wobec takiego zachowania zaproponowała chłopcu udział w spektaklu teatralnym. Chłopiec początkowo mocno się wzbraniał, w końcu przyjął propozycję i zagrał główną rolę. Gdy poznał: „co Korczak robił dla dzieci 
A. RZYMEeKA-FrąCKIEWICZ, T. WILK $\$$ OdMIENNOŚĆ A POCZUCIE BEZPIECZENSSTWA 339

w prowadzonym przez siebie domu dziecka, wpadł w zachwyt" (Winnicka, 2015, s. 28). Dopiero to teatralne doświadczenie - poznanie Korczaka i jego aktywności wobec dzieci - pozwoliło mu zrozumieć, kim byli Żydzi i jak niesprawiedliwe są powtarzane o nich pogłoski/złośliwości.

Dyrektorka zapytana, co powiedziałaby nauczycielom wzbraniającym się przed przyjęciem do szkoły uchodźców z różnych stron świata, także kultury muzułmańskiej, odpowiedziała: „napisałabym, że musimy zrozumieć, że wszyscy jesteśmy przede wszystkim ludźmi. Jako ludzie mamy jedna wielką ojczyznę - Ziemię, a różnorodność jest bogactwem, a nie zagrożeniem dla naszej kultury i tożsamości. Dla nas, przez dziesięciolecia żyjących w homogenicznym świecie, kontakt z ludźmi z odległych kultur to czysty zysk. Musimy też wiedzieć, jak groźna jest wrogość wobec ludzi, którzy przybywają do naszej ojczyzny. Takie nastawienie dzieci w szkole wobec przybyszy i niechęć wobec cudzoziemców podsycana przez rodziców całkowicie uniemożliwiają integrację. Wrogość rodzi wrogość, dlatego jest taka groźna" (Winnicka, 2015, s. 28). W tej sytuacji to przed szkołą właśnie rysuje się istotne zadanie wyprowadzania młodego pokolenia ze złego myślenia, obecnych stereotypów i wprowadzania poprzez edukację/przykład/doświadczenie w budującą i bogatą różnorodność. W kontekście zarysowanych globalnych wyzwań edukacyjnych coraz częściej lansowane są zadania edukacji, których realizacja służy przygotowaniu człowieka do świadomego i odpowiedzialnego życia w warunkach komplikującego się świata. Wśród nich jako priorytetowe warto między innymi potraktować zadania - dialogu między kulturami świata, uczenia zrozumienia i tolerancji (Szempruch i Smyła, 2020, s. 70).

Nadrzędnym przesłaniem współczesnych społeczeństw jest zatem edukacja międzykulturowa, którą Jerzy Nikitorowicz rozumie jako: „ogół wzajemnych wpływów i oddziaływań jednostek i grup, instytucji, organizacji, stowarzyszeń, związków sprzyjających takiemu rozwojowi człowieka, aby stawał się on w pełni świadomym i twórczym członkiem wspólnoty rodzinnej, lokalnej, regionalnej, wyznaniowej, narodowej, kontynentalnej, kulturowej, globalnej - planetarnej oraz był zdolny do aktywnej samorealizacji, kształtowania trwałej tożsamości i odrębności. Skutkiem edukacji ma więc być dynamizacja społeczno-kulturowa różnych grup, wzajemne poznanie, zbliżenie i integracja, z zachowaniem własnej odrębności i własnych wizji rozwoju" (Nikitorowicz, 2009, s. 282).

Wobec powyższego edukacja międzykulturowa winna być systematycznie realizowana w szkole zarówno podstawowej, jak i średniej. To szkoła „ma nie tylko przekazywać wiedzę i umiejętności, jej powinnością jest wprowa- 
dzanie młodzieży w szeroko pojęty świat wartości i kulturę narodową. Ważnym zadaniem szkoły jest również inspirowanie postawy twórczej, otwartej, wdrażanie do samodzielności myślenia i działania, rozwijanie zdolności do samokształcenia. Szkoła ma przygotować nowe pokolenie do pluralizmu, demokracji, tolerancji, otwartości, równości, dialogu; ma uczyć współdziałania, współpracy i współżycia w skomplikowanym układzie globalnym oraz odpowiedzialności globalnej" (Bereźnicki, 2007, s. 256). Szkoła jako instytucja ucząca ma nie tyle przekazywać wiedzę, gotowe rozwiązania, co uczyć poszukiwać i samodzielnie rozwiązywać sytuacje problemowe, to też kształcenie do samokształcenia. Ukazanie wielu problemowych/konfliktowych sytuacji w otaczającej rzeczywistości, prowokowanie pytań, może być najlepszym mechanizmem samodzielnego poznania i próby zmiany sposobu myślenia o odmienności.

„Edukacja, choć zakorzeniona jest w przeszłości i czerpie obficie z teraźniejszości, to ukierunkowana jest, zwłaszcza w czasach współczesnych, na nadchodzące jutro, na przygotowanie do życia w przyszłości wyznaczonej szybkim tempem zmian rozwoju cywilizacji i związanych z nią nadziei, zagrożeń i wyzwań" (Duraj-Nowakowa, 2012, s. 233).

\section{Refleksje końcowe}

Film i teatr dają możliwości specyficznej edukacji oraz osiągnięcia dialogu w przestrzeni międzykulturowej. Dostrzegał to Józef Szajna - autor, scenograf, dramatopisarz i reżyser, prezentując swoje przemyślenia w Orędziu z okazji Międzynarodowego Dnia Teatru w 2007 roku, zatytułowanym - Teatr, nadzieja na pojednanie, w którym czytamy: „Nasze życiorysy bywają różne, są jednak podobne. Co nas różni? Nasze wczoraj i historia. Łączy nas dialog, a także uniwersalizm - w perspektywie zaś, paradoksalnie wspólne jutro. Od stuleci, to wszystko zawiera teatr, nasz dom i kolebka, my jesteśmy jego sługami [...] Teatr jest sztuką otwartą na przeobrażenia czasu, integruje nasze złożone intuicje i idee. [...] Nie tylko uczy ale i wychowuje. Tak pojęte współuczestnictwo sprawia, że stajemy się sobie bliscy, nie tylko tu i teraz, ale także przez treści ogólnoludzkie, poprzez zaangażowanie w to co czynimy. [...] Akt twórczy (...) uczy pokory, pozbawia nas próżności i pychy. Tę sztukę nazywam Te-Artem. Jej przesłaniem, kształtem finalnym jest moralitet, katharsis, oczyszczenie w chwili zagrożenia wartości, życia i kultury. Jest to krzyk w chwili, gdy człowiek sam siebie pomniejsza i zaniedbuje. [...]. Tej ludzkiej nieroztropności przeciwstawiam Dom Sztuki, którym był, jest 
A. RZYMEeKa-FrąCKIEWICZ, T. WilK $\$$ OdMIENNOŚĆ A POCZUCIE BEZPIECZEŃNTTWA 341

i pozostanie teatr. Tu, w teatrze będziemy wznosić GÓRĘ NADZIEI na pojednanie WSCHODU z ZACHODEM (Szajna, 2007).

To dosłowne odniesienie do potrzeby oswajania odmienności, budowania dialogu, który nie tylko realnie, ale i metaforycznie można odnieść do potrzeby pokojowego współistnienia wszystkich narodów. Podobny sposób myślenia o teraźniejszości i przyszłości prezentowali uczestnicy - twórcy, naukowcy i politycy - Europejskiego Kongresu Kultury, który odbywał się we Wrocławiu w 2011 roku. Potwierdzeniem wrażliwości, świadomości i zainteresowania wprowadzenia niezbędnych zmian w sposobie myślenia o odmienności kulturowej było hasło przewodnie Kongresu - Kultura dla zmiany społecznej, wokół którego oscylowały wszystkie konferencje, spotkania oraz wydarzenia artystyczne.

Człowiek i jego los od wieków pozostaje w polu zainteresowania artystów, nie tylko ilustrując jego doświadczenia, ale także próbując zainspirować własnym dziełem odbiorcę, by podjął rozważania i dyskusję w problematycznym zakresie. Także te wskazane w naszych rozważaniach spektakle czy filmy stanowią ilustrację i inspirację wobec możliwości i powinności zmiany powszechnego społecznego myślenia o odmienności.

\section{Bibliografia}

Bauman, Z. 2006. Ptynna nowoczesność. Kraków: Wydawnictwo Literackie. Bauman, Z. 2011. Kultura w ptynnej nowoczesności. Warszawa: Państwowy Instytut Audiowizualny.

Beck, U. 2002. Społeczeństwo ryzyka. W drodze do innej nowoczesności. Warszawa: Wydawnictwo Naukowe Scholar.

Bereźnicki, F. 2007. Dydaktyka. Wybrane zagadnienia. Szczecin: Uniwersytet Szczeciński.

Beuys, J. 1990. Teksty, komentarze, wywiady. Wybór, oprac., wstęp J. Jedliński. Warszawa: Wydawnictwo Akademii Ruchu i Centrum Sztuki Współczesnej.

Chymkowski, R., Dudzik, W. i Wójtowski, M. 2003. Wiedza o kulturze. Warszawa: WSiP.

Duraj-Nowakowa, K. 2012. Uniwersalne wartości kultury kształtowania profesjonalnej gotowości pedagogów/nauczycieli. W: Nowakowska-Kempna, I. red. Uniwersalne wartości kultury w edukacji i terapii. Kraków: Wydawnictwo WAM, ss. 227-242. 
Gawrak, Z. 1962. Jan Epstein. Studium natury w sztuce filmowej. Warszawa: Wydawnictwa Artystyczne i Filmowe.

Hardin, R. 2008. Zaufanie i społeczeństwo. W: Sztompka, P. i Bogunia-Borowska, M. red. Socjologia codzienności. Kraków: Wydawnictwo Znak, ss. $525-559$.

Hausbrandt, A. 1983. Teatr w społeczeństwie. Warszawa: WSiP.

Hohensee-Ciszewska, H. 1976. Podstawy wiedzy o sztukach plastycznych.

Warszawa: WSiP.

Inge, W. 1958. Théâtre Arts. 8.

Lewicki, B. red. 1984. Kino i telewizja Warszawa: WSiP.

Nikitorowicz, J. 2009. Edukacja regionalna i międzykulturowa. Warszawa: WAiP.

Schneider, A. 1961. Théâtre Arts. 3.

Szempruch, J. i Smyła, J. 2020. Wyzwania edukacyjne współczesnego świata

a odpowiedzialność i etyczność działań nauczyciela. W: Rzymełka-Frąckiewicz, A. i Wilk, T. red. Problematyczność rozwoju człowieka w obszarze edukacji i kultury wspótczesnej. Socjopedagogiczne szkice polemiczne.

Torun: Wydawnictwo Edukacyjne Akapit, ss. 67-81.

Suchodolski, B. 2003. Edukacja permanentna: rozdroża i nadzieje. Warszawa:

Towarzystwo Wolnej Wszechnicy Polskiej.

Szajna, J. 2007. Orędzie na Międzynarodowy dzień teatru. Polski Ośrodek ITI. Wilkinson, I. 2008. W stronę socjologicznej konceptualizacji problemu lęku.

W: Sztompka, P. i Bogunia-Borowska, M. red. Socjologia codzienności. Kraków: Wydawnictwo Znak, ss. 856-883.

Winnicka, E. 2015. Kolorowanie biało-czerwonego. Polityka. 46, ss. 26-28. Wojnar, I. 1970. Estetyka i wychowanie. Warszawa: PWN.

Wojnar, I. 1984. Sztuka jako „podręcznik życia”. Warszawa: Nasza Księgarnia.

\section{Dissimilarity versus feeling of safety - what we can and should change in our thinking about Others in a film and theatrical illustration}

Abstract: One of many modern images is the mutual functioning of people who represent different cultures, nationality, race, and religion. This causes a number of misunderstandings or conflicts in individual communities, motivated by a lack of knowledge about each other's culture. The increasingly common dissimilarity in modern societies, generating multiple fears and anxieties, makes it impossible to 


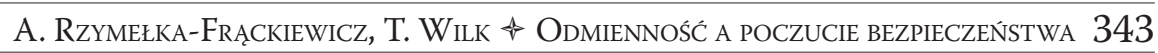

maintain a sense of security. Meanwhile, variety - cultural, ethnic, national diversity - should be seen as a common good for building communities. Thus, there is a lack of awareness that cultural diversity is a value, a specific richness that determines the broad possibilities of holistic development rather than a threat to identity or freedom. In order to achieve this, awareness and knowledge are needed. This text is therefore an attempt to interest the society in the subject matter, which can be tamed and developed through intercultural education, which can take various forms, including specific fields of art, such as theater or film. These art fields are not only a field of education, learning about diversity, but they are a tool for shaping attitudes, interests, expressing emotions, modelling the way of thinking about diversity.

The suggested (selected) performances or films are mostly based on the full conviction that art is not only an autotelic and artistic value, but is a tool that shapes the direction of thinking within a certain range.

Keywords: difference, security, thinking, art, intercultural education

Translated by Agata Rzymełka-Frąckiewicz and Teresa Wilk 